\title{
Perbandingan Model Hybrid ARIMA-NN dan Hybrid ARIMA-GARCH untuk Peramalan Data Nilai Tukar Petani di Provinsi Gorontalo
}

\author{
Isran K. Hasan ${ }^{1, \text { a) }}$, Ismail Djakaria ${ }^{1, b)}$ \\ ${ }^{1}$ Program Studi Statistika, Fakultas Matematika dan IPA, Universitas Negeri Gorontalo, Gorontalo

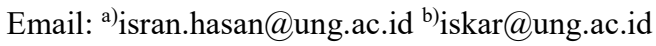

\begin{abstract}
Exchange Rate of Farmers (ERF) is one of the markers of farmer's welfare level. High ERF will encourage farmers' enthusiasm in farming so that a forecast of ERF is needed that will provide benefits for the local government of Gorontalo Province. In this research, ERF forecasting will be carried out using a hybrid model, namely the ARIMA-GARCH hybrid and the ARIMA-NN hybrid. Each of these models is determined by the best model. the best ARIMA-GARCH hybrid model is the ARIMA $(2,0,0)$ GARCH $(1,1)$ model. Meanwhile, the best ARIMA-NN model is the ARIMA model $(2,0,0)$ with NN architecture (2-4-1). From the two models, the ARIMA $(2,0.00)$ - NN (2-4-1) model is the best model with MAPE and RMSE values for ERF are 0.043831 and 4.651419, respectively.
\end{abstract}

Keywords: exchange rate of farmers, hybrid ARIMA, neural network, model GARCH

\begin{abstract}
Abstrak
Nilai Tukar Petani (NTP) adalah salah satu penanda tingkat kesejahteraan petani. NTP yang tinggi akan mendorong kegairahan petani dalam berusaha tani sehingga dibutuhkan suatu peramalan dari NTP yang akan memberikan manfaat buat pemerintah daerah Provinsi Gorontalo. Pada penelitian ini akan dilakukan peramalan NTP dengan menggunakan hybrid model yaitu hybrid ARIMA-GARCH dan hybrid ARIMANN. Masing - masing model tersebut ditentukan model terbaik. Untuk model hybrid ARIMA-GARCH terbaik adalah model ARIMA $(2,0,0)$-GARCH $(1,1)$. Sedangkan untuk model ARIMA-NN Terbaik adalah model ARIMA $(2,0,0)$ dengan arsitektur NN (2-4-1). Dari Kedua model tersebut, diperoleh model ARIMA $(2,0,0)$ - NN(2-4-1) merupakan model paling baik dengan nilai MAPE dan RMSE berturut-turut adalah untuk peramalan data NTP adalah 0.043831dan 4.651419 .
\end{abstract}

Kata-kata kunci: nilai tukar petani, hybrid ARIMA, neural network, model GARCH 


\section{PENDAHULUAN}

Berdasarkan PDRB Provinsi Gorontalo tahun 2020, Sektor pertanian memberikan sumbangan sebesar 28.66\% (PEMPROV, 2020). Hal ini berarti secara garis besar bahwa Sebagian penduduk di Provinsi Gorontalo masih mengantungkan hidupnya pada sektor pertanian sehingganya dibutuhkan pembangunan berkelanjutan pada sektor pertanian. Pembangunan pertanian pada dasarnya ditujukan bagi peningkatan kesejahteraan masyarakat terutama petani. Untuk itu diperlukan sebuah alat ukur yang dapat menilai perkembangan kesejahteraan petani. Alat ukur yang sering kali digunakan untuk mengukur kesejahteraan petani adalah Nilai Tukar Petani (NTP). NTP merupakan satu-satunya penanda kesejahteraan rumah tangga tani bagi pengamat pembangunan pertanian (Simatupang and Maulana, 2006). NTP dihitung dengan membandingkan antara indeks harga yang diterima oleh petani (It) dengan indeks harga yang dibayar oleh petani (Ib). NTP disamping menggambarkan kekuatan daya beli komoditas yang diusahakan juga berkaitan dengan perilaku ekonomi rumah tangga, karena proses pengambilan keputusan rumah tangga untuk memproduksi, membelanjakan dan mengkonsumsi suatu barang merupakan bagian dari perilaku ekonomi rumah tangga. Nilai tukar petani yang tinggi akan mendorong kegairahan petani dalam berusaha tani. Oleh Karena itu, dibutuhkan suatu peramalan dari NTP yang akan memberikan manfaat buat pemerintah daerah Provinsi Gorontalo berupa gambaran mengenai NTP dimasa yang akan datang dan dapat dijadikan acuan dalam pengambilan keputusan untuk meningkatkan sektor pertanian di Provinsi Gorontalo.

Dalam ilmu statistika ada beberapa model yang dapat meramalkan suatu data pada waktu yang akan datang. Analisis runtun waktu merupakan salah satu model peramalan yang paling populer saat ini karena menggunakan data masa lalu yang akan dijadikan acuan untuk peramalan masa depan (Cryer and Chan, 2010). Teknik peramalan time series terbagi menjadi dua bagian yaitu pertama model peramalan yang didasarkan pada model matematika statistik seperti Auto Regressive (AR), Moving Average (MA), Exponential Smoothing, Auto Regressive Integrated Moving Average (ARIMA), Autoregressive Conditional Heteroscedasticity (ARCH) dan Generalized Autoregressive Conditional Heteroscedasticity (GARCH) (Cowpertwait and Metcalfe, 2009). Kemudian ada model peramalan didasarkan pada kecerdasaan buatan seperti Neural Network, Algoritma Genetika, Simulated Annealing, Neural network (Kingdon, 1997) serta model Hybrid time series (Zhang, 2003a). Berdasarkan klasifikasinya metode runtun waktu yang dijelaskan di atas dapat diklasifikasikan menjadi model linier dan model non-linier. Contoh model linier adalah model ARIMA sedangkan model non-linier adalah ARCH, GARCH, dan Neural Network.

Menurut (Zhang, 2003b) salah satu alternatif dalam metode peramalan statistik adalah dengan mengkombinasikan antara model linier dan model non-linier. Kombinasi ini sering kali disebut hybrid-model. Ada tiga hal yang menjadi alasan penggunaan hybrid model. Pertama, sering terjadi kesulitan untuk menerapkan penggunaan model linear dan nonlinear pada suatu kasus time series maka model kombinasi ini menjadi alternatif yang lebih mudah. Kedua, dalam kenyataannya time series jarang yang ada linear atau nonlinear dan sering mengandung keduanya, dimana bukan hanya model linear dan nonlinear masing-masing dapat memodelkan setiap kasusnya sehingga pengkombinasian ini dapat digunakan untuk memodelkan time series yang mengandung linear dan nonlinear. Ketiga, terdapat di dalam beberapa literatur peramalan menyatakan bahwa tidak ada model tunggal yang terbaik pada setiap situasi.

Oleh karena itu, pada penelitian ini, peneliti mengambil model hybrid karena jika ditinjau secara visual pada GAMBAR 1 bahwa plot data runtun waktu dari NTP merupakan gabungan dari data linier dan non-linier sehingga lebih cocok dimodelkan dengan model Hybrid. Hal ini akan di uji lagi pada bagian pembahasan. 


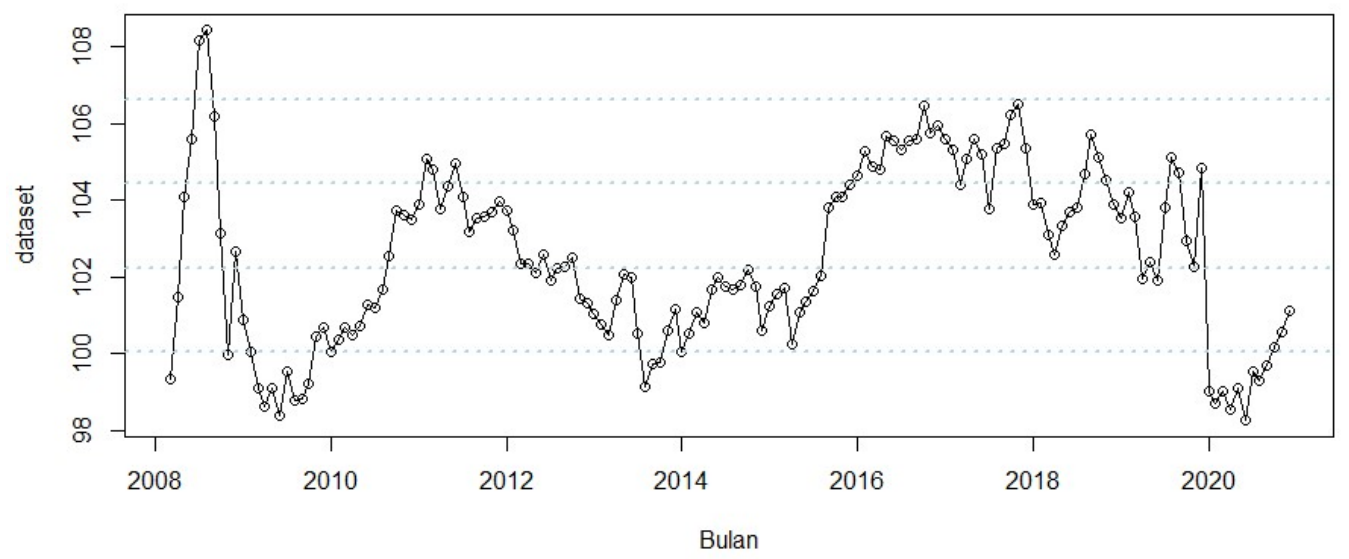

GAMBAR 1. Data NTP-PR dari tahun 2008-2020

Model hybrid yang akan digunakan adalah model dengan mengkombinasikan model ARIMA dan model GARCH (ARIMA-GARCH) serta Model ARIMA dengan neural network. Pemilihan model ini didasarkan pada penelitian sebelumnya yang melakukan prediksi pada nilai NTP yaitu (Desvina and Meijer, 2018) yang menghasilkan model terbaik adalah Model ARCH (1) dengan MAPE sebesar $3.64 \%$ serta (Khusniyah and Sutikno, 2016) yang menghasilkan model neural network dengan 7 neuron menghasilkan error sebesar $0.61 \%$. Selain itu, telah banyak dilakukan penelitian terkait metode ARIMA-GARCH diantaranya (Faustina, Agoestanto and Hendikawati, 2017), (Qasim et al., 2021) dan (Dritsaki, 2018). Ketiga artikel tersebut menghasilkan model terbaik adalah model ARIMAGARCH dengan ukuran ketepatan bervariasi. Sedangkan untuk model ARIMA-NN telah dilakukan oleh (Zhang, 2003b), (Susanto and Ulama, 2016) dan (Escudero, Alcocer and Paredes, 2021) yang meneliti dengan berbagai algoritma untuk neural network yang menghasilkan galat terkecil.

Berdasarkan masalah dan penelitian sebelumnya tersebut, peneliti tertarik untuk menerapkan serta membandingkan perfoma dari model runtun waktu ARIMA-GARCH dan ARIMA-NN. Selanjutnya, model terbaik akan digunakan peramalan nilai tukar petani di Provinsi Gorontalo.

\section{METODOLOGI}

\section{Bahan dan Data}

Data yang digunakan pada penelitian ini adalah data sekunder yang diperoleh dari website BPS Provinsi Gorontalo (BPS, 2020). Data ini merupakan data Nilai Tukar Petani dari Tahun 2008-2020. Selanjutnya data tersebut dibagi menjadi dua bagian yakni data in-sample yang dimulai dari Januari 2008- Desember 2019 dan data out-sample dari bulan Januari 2020 - Desember 2020.

\section{Metode Penelitian}

Metode yang digunakan dalam penelitian ini adalah studi literatur dengan menelusuri jurnal-jurnal dan buku teks yang terkait dengan Model time series, model GARCH serta model neural network. Selanjutnya, Software yang digunakan pada penelitian ini adalah software Rstudio versi 1.4.1717. Berikut langkah-langkah pemodelan dan peramalan pada penelitian ini

\section{Prepocessing data dan Identifikasi model}

Pada tahapan ini akan dilakukan pemrosesan awal untuk data NTP untuk melihat adanya data yang tidak lengkap atau missing value yang akan menganggu proses pemodelan dan peramalan. Selain, melihat ada tidaknya kelengkapan data, pada tahapan ini juga dilihat adanya tidaknya outlier serta 
indikasi komponen non-linier pada data. Pengujian outlier dianggap perlu karena data outlier akan memberikan pengaruh yang besar pada peramalan khusus jika metode peramalan menggunakan metode ARIMA (Ahmar et al., 2018). Selain itu, pengujian komponen linier juga diperlukan khususnya pada penerapan neural network pada data runtun waktu (Medeiros, Teräsvirta and Rech, 2006). Selanjutnya akan diuji asumsi kestasoneran dengan melihat pola ACF dan PACF serta diperkuat lagi dengan uji Augmented Dickey Fuller.

Setelah melihat hasil prepocessing data, proses akan dilanjutkan dengan identifikasi model ARIMA untuk menentukan orde ARIMA yang terbaik. Proses ini dilakukan dengan cara melihat plot ACF dan PACF untuk menentukan orde ARIMA (William W. S., 2005). Selanjutnya dilakukan proses estimasi parameter dan uji diagnostik dari model yang telah ditentukan sebelumnya. Dari proses ini, dihasilkan model terbaik yang akan digunakan pada model hybrid.

\section{Pemodelan dengan hybrid ARIMA-GARCH}

Model hybrid ARIMA (p,q)-GARCH (P,Q) secara matematis dapa dituliskan sebagai berikut (Pahlavani and Roshan, 2015):

Dimana

$$
Y_{t}=\mu+\phi_{1} Y_{t-1}+\cdots+\phi_{p} Y_{t-p}+\varepsilon_{t}+\theta_{1} \varepsilon_{t-1}+\cdots+\theta_{q} \varepsilon_{t-q}
$$

$$
\begin{gathered}
\varepsilon_{t}=\sigma_{t} \cdot v_{t} \\
\sigma_{t}^{2}=\omega+\alpha_{1} \sigma_{t-1}^{2}+\cdots+\alpha_{p} \sigma_{t-p}^{2}+\beta_{1} \varepsilon_{t-1}^{2}+\cdots+\beta_{q} \varepsilon_{t-q}^{2}
\end{gathered}
$$

Selanjutnya akan disusun dilangkah-langkah model Hybrid ARIMA-GARCH. Langkah ini diperoleh berdasarkan kajian dari beberapa artikel ilmiah diantaranya (Faustina, Agoestanto and Hendikawati, 2017) dan (Rosadi, 2021). Adapun langkah-langkah sebagai berikut:

1. Menentukan nilai forecasting dan residual dari model terbaik yang telah diperoleh sebelumnya.

2. Melakukan uji efek ARCH pada kuadrat residual kuadrat dari model ARIMA

3. Mengestimasi parameter model GARCH untuk residual dan memilih model GARCH terbaik berdasarkan signifikansi parameter dan nilai AIC

4. Melakukan Forecasting nilai residual dari model GARCH terbaik

5. Mengabungkan Hasil 1) dan 4) sehingga diperoleh hasil peramalan

\section{Pemodelan dengan hybrid ARIMA-NN}

Secara umum, model Hybrid ARIMA-NN dapat dirumuskan sebagai berikut:

$$
y_{t}=L_{t}+N_{t}
$$

Dimana $L_{t}$ adalah komponen linier yang diperoleh dari model ARIMA. Sedangkan $N_{t}$ merupakan komponen non linier yang diperoleh dengan memodelkan residual dari model ARIMA. Berikut Langkah-langkah model Hybrid ARIMA-NN yang diperoleh dari merangkum dari beberapa artikel ilmiah diantaranya (Susanto and Ulama, 2016), (Kusumaningrum, Suhartono and Haryono, 2012) dan (Janah, Sulandari and Wiyono, 2014):

1. Menentukan nilai forecasting dan residual dari model terbaik yang telah diperoleh sebelumnya.

2. Menentukan variable input untuk pemodelan ARIMA-NN berdasarkan Residual yang diperoleh dari peramalan model ARIMA terbaik.

3. Menentukan jumlah neuron, bobot awal serta fungsi aktivasi

4. Melakukan training pada data in-sample berdasarkan arsitektur NN yang telah ditentukan.

5. Melakukan peramalan berdasarkan hasil training. 
Setelah diperoleh model terbaik dari masing-masing model tersebut, proses selanjutnya adalah melakukan perbandingan dari masing-masing model terbaik baik dari model ARIMA-GARCH maupun dari ARIMA-NN.Perbandingan ini dilakukan dengan melihat nilai MAPE dan RMSE dari out-sample lalu akan dilihat nilai MAPE dan RMSE yang terkecil.

\section{HASIL DAN PEMBAHASAN}

\section{Pre-Pocessing Data dan Identifikasi Model}

Prepocessing data dilakukan sebagai Langkah awal dalam memproses data agar diperoleh data yang telah siap diolah sesuai dengan metode yang ditetapkan. Pada GAMBAR 1, terlihat bahwa data NTP di Provinsi Gorontalo tidak terdapat missing value yang akan menganggu proses peramalan. Selanjutnya akan dilihat keberadaan outlier pada data serta menguji adanya indikasi komponen nonlinier pada data. Pada penelitian ini, pengujian outlier menggunakan Uji Grubbs sedangkan pengujian komponen non-linier menggunakan uji Terasvirta. Hasil pengujian ditampilkan pada TABEL 1.

\begin{tabular}{ccc}
\begin{tabular}{c} 
TABEL 1. Nilai $P$-Value untuk Uji Grubbs dan Uji Terasvirta \\
\hline $\begin{array}{c}\text { Variabel } \\
\text { Input }\end{array}$
\end{tabular} & $\begin{array}{c}\text { Grubbs Test } \\
(\boldsymbol{P} \text {-Value })\end{array}$ & $\begin{array}{c}\text { Terasvirta } \\
(\boldsymbol{P} \text {-Value })\end{array}$ \\
\hline Data NTP & 0.6646 & 0.63 \\
\hline
\end{tabular}

Berdasarkan TABEL 1, terlihat bahwa data NTP tidak ada indikasi data outlier karena P-Value yang dihasilkan lebih besar dari $\alpha=5 \%$ dengan hipotesis alternatif adalah terdapat data outlier. Hal yang sama juga diperoleh dari uji Terasvirta dengan $\alpha=5 \%$ diperoleh kesimpulan bahwa model tersebut merupakan model non-linier.

Selanjutnya, karena model ARIMA membutuhkan satu asumsi lagi yaitu asumsi kestasioneran. Oleh karena itu, Data NTP akan dicek kestasionerannya dengan melihat pola Autocorrelation Function (ACF), Partial Autocorrelation Function (PACF) serta diperkuat dengan uji augmented Dickey Fuller (ADF).
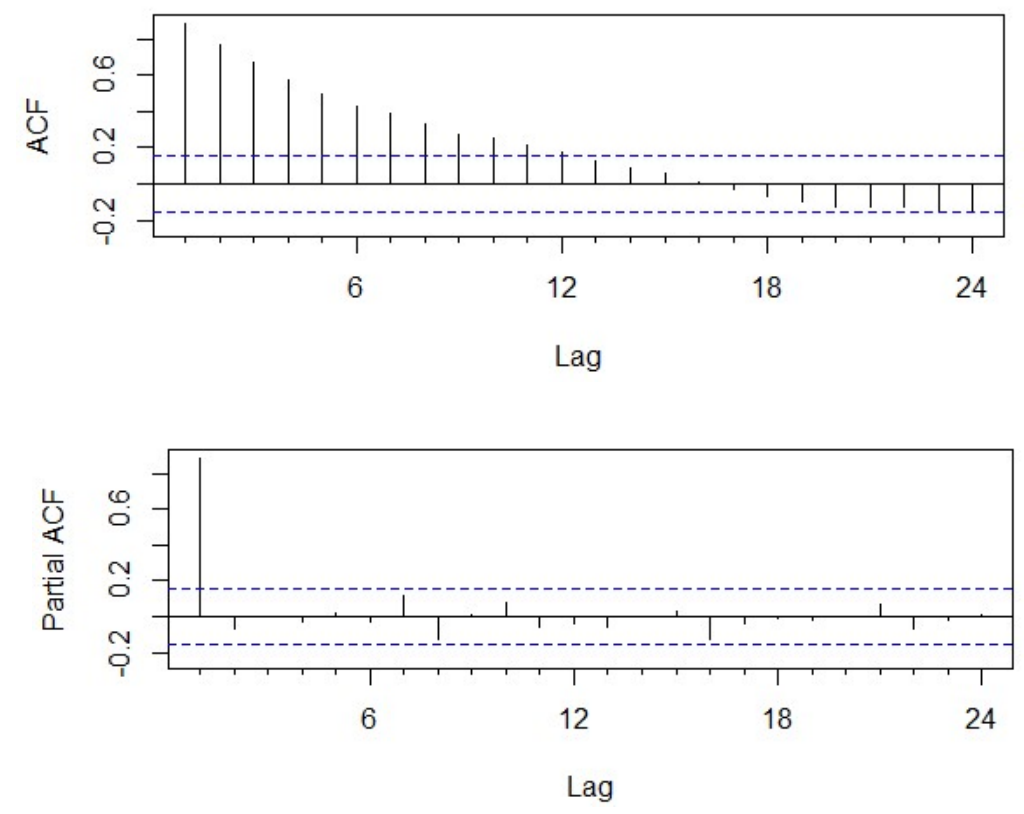

GAMBAR 2. Plot ACF dan PACF data NTP

Dari GAMBAR 2, dapat dilihat bahwa fungsi ACF pada setiap lag turun secara ekponensial yang menandakan bahwa data sudah stasioner. Selanjutnya, dengan uji ADF diperoleh P-Value lebih kecil 0.01 dengan dengan $\alpha=5 \%$ sehingga diperoleh kesimpulan data NTP sudah stasioner. 
Berdasarkan GAMBAR 2 juga terlihat bahwa fungsi ACF meluruh secara eksponensial menuju nol sedangkan fungsi PACF mengalami cut off pada lag 1. Dari sini dapat disimpulkan alternatif model ARIMA yaitu model AR (1) serta model overfitting dari model tersebut yaitu model AR(2), $\operatorname{ARMA}(1,1)$. Tahapan selanjutnya setelah identifikasi model adalah tahapan estimasi parameter dari model yang telah disebutkan di atas. Pada TABEL 2 akan ditampilkan signifikansi parameter dan hasil cek diagnostik dari model ARIMA yang telah didentifikasi pada bagian 3.1.

TABEL 2. Signifikansi dan Hasil Cek Diagnostik dari Model ARIMA

\begin{tabular}{|c|c|c|c|}
\hline & ARIMA $(1,0,0)$ & ARIMA $(2,0,0)$ & ARIMA $(1,0,1)$ \\
\hline \multirow[t]{2}{*}{$\mathrm{AR}(1)$} & 0.9036 & 1.1200 & 0.8622 \\
\hline & $\mathrm{SE}=0.0359$ & $\mathrm{SE}=0.0851$ & $\mathrm{SE}=0.0468$ \\
\hline \multirow[t]{2}{*}{$\mathrm{AR}(2)$} & & -0.2374 & \\
\hline & & $\mathrm{SE}=0.0852$ & \\
\hline \multirow[t]{2}{*}{ MA(1) } & & & 0.2483 \\
\hline & & & $\mathrm{SE}=0.0859$ \\
\hline \multirow[t]{2}{*}{ INTERCEPT } & 102.7350 & 102.7737 & 102.7713 \\
\hline & $\mathrm{SE}=0.7646$ & $\mathrm{SE}=0.6258$ & $\mathrm{SE}=0.6623$ \\
\hline RMSE & 0.9334375 & 0.9085391 & 0.909275 \\
\hline AIC & 391.11 & 385.56 & 385.78 \\
\hline $\mathrm{Q}(12)$ & 11.593 & 8.8711 & 7.5519 \\
\hline (P-Value) & $(0.4789)$ & $(0.7139)$ & $(0.8191)$ \\
\hline $\mathrm{Q}(24)$ & 19.593 & 17.38 & 15.228 \\
\hline (P-Value) & $(0.7197)$ & $(0.832)$ & $(0.9139)$ \\
\hline $\mathrm{Q}(36)$ & 21.48 & 20.843 & 18.979 \\
\hline (P-Value) & $(0.9736)$ & $(0.9795)$ & $(0.9912)$ \\
\hline
\end{tabular}

Dari TABEL 2, dilihat bahwa parameter dari semua model memiliki parameter yang signifikan selanjutnya dari uji diagnostik dengan uji Ljung-Box, terlihat bahwa nila p-value untuk semua model tersebut pada semua lag bernilai lebih besar dari $\alpha=5 \%$. Hal ini berarti bahwa ketiga model tersebut memiliki koefisien yang signifikan dan memenuhi uji diagnostik tidak adanya korelasi pada residual tersebut. Selanjutnya, untuk menentukan model ARIMA terbaik dipilih berdasarkan nilai Akaike Information Criteria (AIC) dan RMSE diperoleh model terbaik adalah model ARIMA $(2,0,0)$. Model ini kemudian akan digunakan pada pemodelan hybrid baik hybrid ARIMA-GARCH maupun Hybrid ARIMA-NN

\section{Model Hybrid ARIMA-GARCH}

Dengan demikian, setelah diperoleh ordo ARIMA pada proses $\left\{Y_{t}\right\}$ yang telah diidentifikasi pada bagian sebelumnya maka langkah selanjutnya adalah menentukan ordo parameter GARCH $(P, Q)$ berdasarkan nilai kuadrat dari residual. Namun, sebelum masuk pada estimasi model GARCH, terlebih dahulu dilakukan proses pengujian ada tidaknya efek ARCH/GARCH pada residual kuadrat. Pengujian ini dilakukan dengan melihat plot ACF dan PACF pada residual kuadrat serta diperkuat dengan menggunakan Portmanteau- $Q$ test (PQ-test) dan Lagrange Multiplier Test (LM-test) yang hasil pengujian dapat dilihat pada GAMBAR 3. 

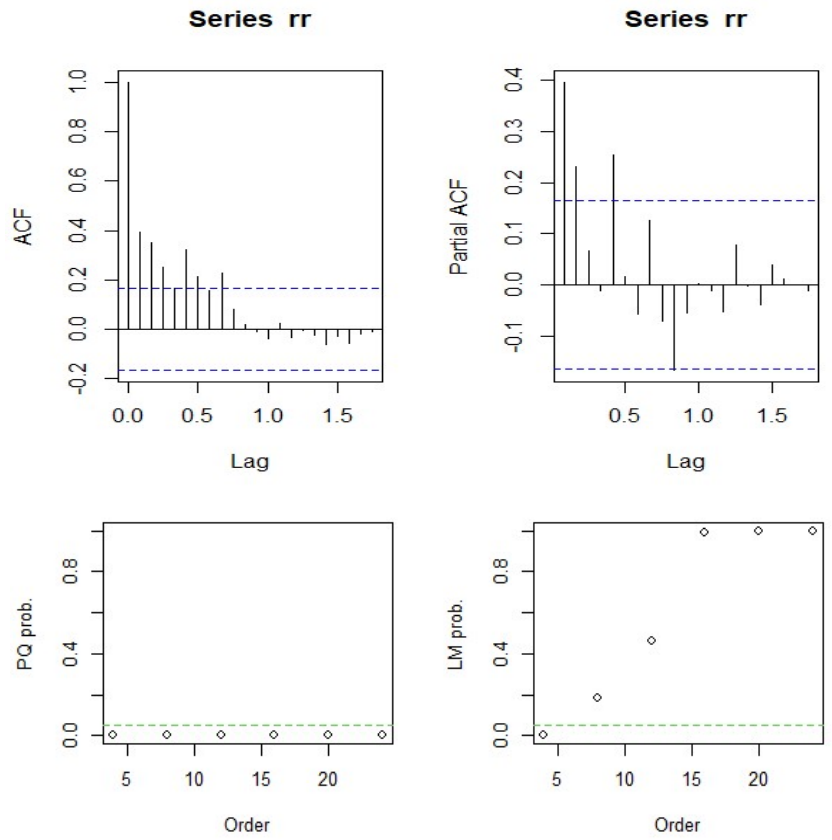

GAMBAR 3. Hasil Plot ACF dan PACF residual Kuadrat (atas) dan hasil Uji PQ-test dan LM-test (bawah)

Berdasarkan GAMBAR 3 diperoleh kesimpulan bahwa terdapat efek ARCH/GARCH pada residual kuadrat karena pada plot ACF dan PACF residual kuadrat terlihat bahwa banyak lag yang melewati garis interval. Selain itu, dari hasil Uji PQ-test dan LM-test bahwa terdapat lag yang berada di bawah garis batas, hal ini semakin memperkuat bahwa terdapat efek ARCH/GARCH pada residual kuadrat.

Tahapan selanjutnya adalah memilih model hybrid ARIMA-GARCH terbaik dengan melihat nilai AIC. TABEL 3 menampilkan hasil AIC dari model hybrid ARIMA-GARCH dengan menentukan orde GARCH yang sederhana berdasarkan prinsip Parsimony.

TABEL 3. Tabel Perbandingan berbagai model hybrid ARIMA-GARCH berdasarkan Nilai AIC

\begin{tabular}{cc}
\hline Model & AIC \\
\hline ARIMA $(2,0,0)-$ GARCH $(1,0)$ & 2.559103 \\
ARIMA $(2,0,0)-$ GARCH $(1,1)$ & 2.498465 \\
ARIMA $(2,0,0)-$ GARCH $(2,0)$ & 2.528615 \\
ARIMA $(2,0,0)-$ GARCH $(2,1)$ & 2.542699 \\
ARIMA $(2,0,0)-$ GARCH $(2,2)$ & 2.624231 \\
\hline
\end{tabular}

Berdasarkan TABEL 3, diperoleh kesimpulan bahwa model terbaik adalah model ARIMA $(2,0,0)$ GARCH $(1,1)$. Selanjutnya, model ini yang digunakan untuk dibandingkan performanya dengan model ARIMA-NN.

\section{Model Hybrid ARIMA-NN}

Tahapan awal dari model ARIMA-NN adalah menentukan nilai input, jumlah neuron serta fungsi aktivasi yang akan digunakan. Pada penelitian ini, jumlah input yang digunakan dimulai disesuaikan dengan parameter ARIMA atau berdasarkan plot ACF dan PACF (Susanto and Ulama, 2016). Oleh karena itu, input pada penelitian ini adalah residual model ARIMA pada lag $1\left(e_{t-1}\right)$ dan lag $2\left(e_{t-2}\right)$ dengan single hidden layer. Selain itu, jumlah neuron yang digunakan pada hidden layer akan divariasikan mulai dari 3 sampai 6 . Selanjutnya, dilakukan prediksi nilai residual untuk periode 12 bulan kedepan. Hasil prediksi ini dijumlahkan dengan hasil prediksi yang diperoleh pada Model ARIMA $(2,0,0)$. TABEL 4 memperlihatkan nilai MAPE dan RMSE out sample dari masing-masing input. 
TABEL 4 Tabel nilai MAPE dan RMSE model ARIMA-NN dengan variasi input dan neuron

\begin{tabular}{lcccc}
\hline Input & $\begin{array}{c}\text { Jumlah } \\
\text { bobot }\end{array}$ & $\begin{array}{c}\text { Jumlah } \\
\text { Neuron }\end{array}$ & MAPE & RMSE \\
\hline \multirow{4}{*}{ dan } & 10 & 3 & 0.046187 & 4.936491 \\
$e_{t-1}$ & 13 & 4 & 0.046334 & 4.948368 \\
bias & 16 & 5 & 0.044952 & 4.889233 \\
& 19 & 6 & 0.046191 & 4.934960 \\
& 22 & 7 & 0.044239 & 4.847765 \\
& 25 & 8 & 0.044872 & 4.877573 \\
\hline \multirow{3}{*}{,$e_{t-2}$} & 13 & 3 & 0.047722 & 5.061143 \\
dan bias & 17 & 4 & 0.043831 & 4.686450 \\
& 21 & 5 & 0.045709 & 4.972285 \\
& 25 & 6 & 0.045196 & 5.015018 \\
& 29 & 7 & 0.045196 & 5.015018 \\
& 33 & 8 & 0.045223 & 5.048209 \\
\hline
\end{tabular}

Dari TABEL 4, diperoleh nilai MAPE dan RMSE yang terkecil adalah pada input pada lag $e_{t-1}$ dan $e_{t-2}$ dengan jumlah neuron 4 dengan nilai MAPE dan RMSE berturut-turut adalah 0.043831dan 4.651419. GAMBAR 4 berikut menjelaskan arsitektur dari model NN (2-4-1).

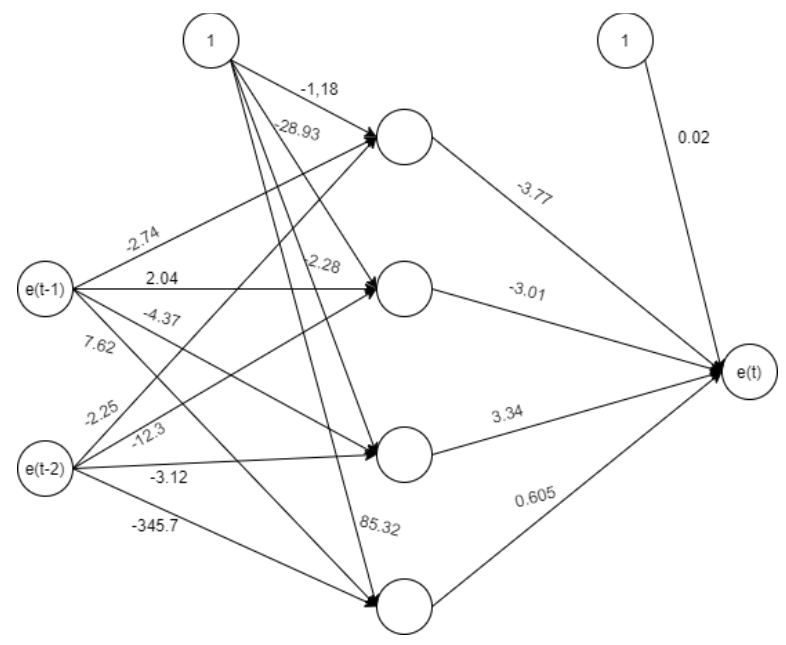

GAMBAR 4. Arsitektur dari model NN (2-4-1)

Dari GAMBAR 4 dapat dibentuk persamaan matematika dengan fungsi aktivasi sigmoid sebagai berikut:

$$
\widehat{e_{t}}=0.02-3.77 h_{1 t}-3.01 h_{2 t}-3.34 h_{3 t}+0.605 h_{4 t}
$$

dengan,

$$
\begin{aligned}
& h_{1 t}=\frac{1}{1+\exp \left(-\left(-1,18-2.74 e_{t-1}-2.25 e_{t-2}\right)\right)} \\
& h_{2 t}=\frac{1}{1+\exp \left(-\left(-28.93+2.04 e_{t-1}-12.3 e_{t-2}\right)\right)} \\
& h_{3 t}=\frac{1}{1+\exp \left(-\left(-2.28-4.37 e_{l-1}-3.12 e_{l-2}\right)\right)} \\
& h_{4 t}=\frac{1}{1+\exp \left(-\left(05.32+7.62 e_{t-1}-345.7 e_{t-2}\right)\right)}
\end{aligned}
$$

berdasarkan persamaan (2) dapat dibentuk persamaan hybrid ARIMA-NN dengan arsitektur NN Residual (2-4-1) sebagai berikut: 


$$
\widehat{Y}_{t}=\widehat{L}_{t}+\widehat{N}_{t}
$$

Dimana $\widehat{L}_{t}=\mu+\phi_{1} Z_{t-1}+\phi_{2} Z_{t-2}$ dan $\widehat{N}_{t}=\hat{e}_{t}$. Selanjutnya dari persamaan ini dapat diperoleh nilai prediksi untuk peramalan dimasa yang akan datang.

\section{Perbandingan Hasil Peramalan Model ARIMA-GARCH dan ARIMA-NN}

Kinerja Model ARIMA(2,0,0), model ARIMA(2,0,0)-GARCH(1,1) dan Model ARIMA-NN dengan arsitektur NN Residual (2-4-1) akan ditunjukkan dengan melakukan peramalan nilai NTP untuk 12 bulan kedepan. GAMBAR 5 memperlihatkan perbandingan nilai peramalan dari bulan Januari 2020 sampai Desember 2020.

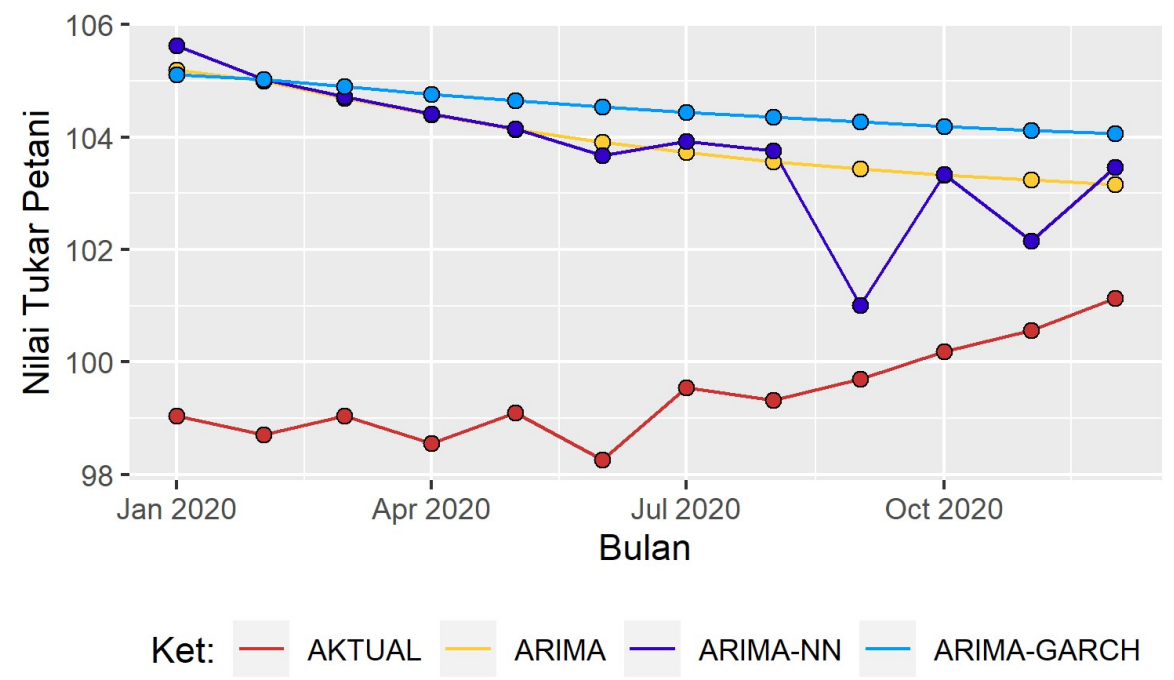

GAMBAR 5. Perbandingan Nilai Peramalan pada Data Out Sample

Berdasarkan GAMBAR 5 terlihat bahwa Model ARIMA (2,0,0)-NN (2-4-1) mampu mendekati nilai aktual dari data nilai tukar petani jika dibandingkan model lainnya. Selanjutnya, untuk menentukan model terbaik dilakukan dengan melihat nilai MAPE dan RMSE dari masing-masing model. TABEL 5 menunjukkan perbandingan nilai MAPE dan RMSE dari masing-masing model.

TABEL 5. Tabel perbandingan nilai MAPE dan RMSE out-sample

\begin{tabular}{lcc}
\hline \multicolumn{1}{c}{ Model } & \multicolumn{2}{c}{ 12 Bulan } \\
\hline Model ARIMA $(2,0,0)$ & 0.0459343 & 4.758959 \\
Model ARIMA $(2,0,0)-G A R C H(1,1)$ & 0.05148482 & 5.226183 \\
Model ARIMA $(2,0,0)-\mathrm{NN}(2-4-1)$ & 0.043831 & 4.686450 \\
\hline
\end{tabular}

Berdasarkan TABEL 5 dapat diperoleh kesimpulan bahwa model yang memiliki MAPE dan RMSE terkecil adalah model hybrid ARIMA (2,0,0)-NN (2-4-1). Hal ini menunjukkan bahwa model tersebut memiliki hasil ramalan yang baik dibanding dua model lainnya dengan selisih nilai MAPE dan RMSE yang sangat kecil. 


\section{KESIMPULAN DAN SARAN}

Berdasarkan hasil dan pembahasan dapat disimpulakan bahwa model ARIMA terbaik adalah model ARIMA $(2,0,0)$ sedangkan model ARIMA-GARCH yang terbaik adalah model ARIMA $(2,0,0)$ GARCH $(1,1)$ dengan melihat nilai AIC dan model hybrid ARIMA-NN terbaik adalah model ARIMA dengan Arsitektur NN (2-4-1). Melalui ketiga model tersebut, dihitung nilai MAPE dan RMSE yang menghasilkan bahwa model ARIMA dengan Arsitektur NN (2-4-1) memiliki nilai MAPE dan RMSE yang paling kecil. Dengan demikian, model ARIMA $(2,0,0)-\mathrm{NN}(2,4,1)$ dapat digunakan sebagai alternatif pemodelan untuk data NTP yang bisa dimanfaatkan untuk pengambilan keputusan dalam bidang pertanian.

\section{UCAPAN TERIMA KASIH}

Kami ucapkan terima kasih untuk LP2M-UNG yang telah memberikan dukungan moril serta dukungan materil melalui dana hibah penelitian dosen pemula dalam penyelesaian artikel ini.

\section{REFERENSI}

Ahmar, A. S. et al. (2018) 'Modeling Data Containing Outliers using ARIMA Additive Outlier (ARIMA-AO)', Journal of Physics: Conference Series, 954(1). doi: 10.1088/17426596/954/1/012010.

BPS (2020) Nilai Tukar Petani. Available at: https://gorontalo.bps.go.id/subject/22/nilai-tukarpetani.html\#subjekViewTab1 (Accessed: 12 March 2021).

Cowpertwait, P. S. P. and Metcalfe, A. V. (2009) Introductory Time Series with R (Use R!). New York: Springer.

Cryer, J. D. and Chan, K.-S. (2010) Time Series Analysis: With Applications in R. New York: Springer.

Desvina, A. P. and Meijer, O. I. (2018) 'Penerapan Model ARCH/GARCH untuk Peramalan Nilai Tukar Petani', Jurnal Sains Matematika dan Statistika, 4(1), pp. 43-54.

Dritsaki, C. (2018) 'The Performance Of Hybrid ARIMA-GARCH Modeling And Forecasting Oil Price', INTERNATIONAL JOURNAL OF ENERGY ECONOMICS AND POLICY, 8(3), pp. 14-21.

Escudero, P., Alcocer, W. and Paredes, J. (2021) 'Recurrent Neural Networks and ARIMA Models for Euro/Dollar Exchange Rate Forecasting', Applied Sciences, 11(12), p. 5658. doi: 10.3390/app11125658.

Faustina, R. S., Agoestanto, A. and Hendikawati, P. (2017) 'Model Hybrid ARIMA-GARCH untuk Estimasi Volatilitas Harga Emas', UNNES Jurnal of Mathematics, 6(1), pp. 11-24.

Janah, S. N., Sulandari, W. and Wiyono, S. B. (2014) 'Penerapan Model Hybrid Arima Backpropagation Untuk Peramalan Harga Gabah Indonesia', Media Statistika, 7(2), pp. 63-69. doi: 10.14710/medstat.7.2.63-69.

Khusniyah, T. W. and Sutikno, S. (2016) 'Prediksi Nilai Tukar Petani Menggunakan Jaringan Syaraf Tiruan Backpropagation', Scientific Journal of Informatics, 3(1), pp. 11-18. doi: 10.15294/sji.v3i1.4970.

Kingdon, J. (1997) Intelligent Systems and Financial Forecasting. New York: Springer.

Kusumaningrum, O., Suhartono, S. and Haryono, H. (2012) 'Peramalan Kebutuhan Bahan Bakar Premium di Depot Ampenan dengan Metode Hibrida ARIMA-Neural Network untuk Optimasi Persediaan', Jurnal Sains dan Seni ITS, 1(1), pp. D194-D200. 
Medeiros, M. C., Teräsvirta, T. and Rech, G. (2006) 'Building neural network models for time series: a statistical approach', Journal of Forecasting, 25(1), pp. 49-75. doi: 10.1002/for.974.

Pahlavani, M. and Roshan, R. (2015) 'The Comparison among ARIMA and hybrid ARIMA-GARCH Models in Forecasting the Exchange Rate of Iran', International Journal of Business and Development Studies, 7(1), pp. 31-50. Available at: http://ijbds.usb.ac.ir/article_2198_4150a14b626373be361539db9796e1de.pdf.

PEMPROV, G. (2020) Kinerja Sektor Pertanian Gorontalo Tahun 2020 Sangat Memuaskan | PROVINSI GORONTALO, gorontaloprov.go.id. Available at: https://gorontaloprov.go.id/kinerjasektor-pertanian-gorontalo-tahun-2020-sangat-memuaskan/ (Accessed: 29 August 2021).

Qasim, T. B., Ali, Hina., Malik, Natasha. and Liaquat, Malika. (2021) 'Forecasting Inflation Applying ARIMA Model with GARCH Innovation: The Case of Pakistan', Journal of Accounting and Finance in Emerging Economies, 7(2), pp. 305-316. doi: 10.26710/jafee.v7i2.1681.

Rosadi, D. (2021) Analisis Runtun Waktu dan Aplikasinya dengan R. Yogyakarta: UGM Press.

Simatupang, P. and Maulana, M. (2006) 'Kaji Ulang Konsep Dan Perkembangan Nilai Tukar Petani Tahun 2003-2006', Jurnal Ekonomi dan Pembangunan LIPI, 5(4), pp. 70-88. Available at: https://doi.org/10.1007/s12571-019-00996-x.

Susanto, Y. and Ulama, B. S. S. (2016) 'Pemodelan Curah Hujan dengan Pendekatan Model ARIMA, Feed Forward Neural Network dan Hybrid (ARIMA-NN) di Banyuwangi', Jurnal Sains dan Seni ITS, 5(2), p. Available http://ejurnal.its.ac.id/index.php/sains_seni/article/viewFile/16409/3032.

William W. S., W. (2005) 'Time Series Analysis: Univariate and Multivariate Methods (2nd Edition)Addison Wesley (2005).pdf’. New York: Addison Wesley, p. 634.

Zhang, G. P. (2003a) Neural Networks in Business Forecasting. Pennsylvania: IDEA GROUP PUBLISHING.

Zhang, G. P. (2003b) 'Time series forecasting using a hybrid ARIMA and neural network model', Neurocomputing, 50, pp. 159-175. doi: 10.1016/S0925-2312(01)00702-0. 